Article

\title{
Evaluation of the Carbon Dioxide Uptake of Slag-Blended Concrete Structures, Considering the Effect of Carbonation
}

\author{
Han-Seung Lee ${ }^{1}$ and Xiao-Yong Wang ${ }^{2, *}$ \\ 1 Department of Architectural Engineering, Hanyang University, Ansan 426-791, Korea; \\ ercleehs@hanyang.ac.kr \\ 2 Department of Architectural Engineering, Kangwon National University, Chuncheon 200-701, Korea \\ * Correspondence: wxbrave@kangwon.ac.kr; Tel.: +82-33-250-6229
}

Academic Editors: Vivian W. Y. Tam, Khoa N. Le and Liyin Shen

Received: 15 February 2016; Accepted: 23 March 2016; Published: 30 March 2016

\begin{abstract}
During the production of concrete, cement, water, aggregate, and chemical and mineral admixtures will be used, and a large amount of carbon dioxide will be emitted. Conversely, during the decades of service life of reinforced concrete structures, carbon dioxide in the environment can ingress into concrete and chemically react with carbonatable constitutes of hardened concrete, such as calcium hydroxide and calcium silicate hydrate. This chemical reaction process is known as carbonation. Carbon dioxide will be absorbed into concrete due to carbonation. This article presents a numerical procedure to quantitatively evaluate carbon dioxide emissions and the absorption of ground granulated blast furnace slag (GGBFS) blended concrete structures. Based on building scales and drawings, the total volume and surface area of concrete are calculated. The carbon dioxide emission is calculated using the total volume of concrete and unit carbon dioxide emission of materials. Next, using a slag blended cement hydration model and a carbonation model, the carbonation depth is determined. The absorbed carbon dioxide is evaluated using the carbonation depth of concrete, the surface area of concrete structures, and the amount of carbonatable materials. The calculation results show that for the studied structure with slag blended concrete, for each unit of $\mathrm{CO}_{2}$ produced, $4.61 \%$ of carbon dioxide will be absorbed during its 50 years of service life.
\end{abstract}

Keywords: carbon dioxide uptake; slag blended concrete; carbonation; hydration; model

\section{Introduction}

Portland cement is the principle hydraulic binder used in modern concrete. The production of one ton of ordinary Portland cement (OPC) generates 0.55 ton of chemical $\mathrm{CO}_{2}$ and requires an additional 0.39 ton of $\mathrm{CO}_{2}$ in fuel emissions, accounting for a total of 0.94 ton of $\mathrm{CO}_{2}$ [1]. The word's yearly cement accounts for nearly $7 \%$ percent of global $\mathrm{CO}_{2}$ emissions [1]. On the other hand, ground granulated blast furnace slag (GGBFS), which is a byproduct of the steel industry, has been increasingly used in the concrete industry as a mineral admixture to partially replace cement. Slag blended concrete has many advantages, such as higher resistance against sulfate and seawater attack, higher late age strength, lower materials cost, and lower $\mathrm{CO}_{2}$ emissions [1].

Carbon dioxide in the environment can ingress into concrete and chemically react with carbonatable constitutes of hardened concrete, such as calcium hydroxide and calcium silicate hydrate. This chemical reaction process is called carbonation. Carbonation presents both advantages and disadvantages to reinforced concrete structures [2]. Carbonation can reduce the porosity of concrete and improve the compressive strength in the carbonated region of concrete. On the other hand, carbonation decreases the alkaline in concrete and induces the corrosion of steel rebar [1]. 
Many investigations have been conducted regarding the experimental and theoretical study of the carbonation of slag blended concrete and the life cycle of the carbon dioxide emission of structural concrete.

Regarding the carbonation of slag blended concrete, Sulapha [3], Elke [4], Sisomphon [5], Monkman [6], and Bernal [7] experimentally found that carbonation of slag-blended concrete correlates to water to binder ratios, slag replacement ratios, and concrete curing methods. By increasing the replacement of slag, the carbonation depth of concrete will increase. Higher carbonation depth does not necessarily mean higher absorption of $\mathrm{CO}_{2}$. It might mean that there is faster diffusion of $\mathrm{CO}_{2}$ due to there being less $\mathrm{CSH}$ to react with. Reducing the water to binder ratio and extending the initial curing period before carbonation tests can reduce the carbonation depth of slag-blended concrete. Papadakis [8,9] proposed chemical reaction equations for cement-mineral admixture blends and evaluated the contents of carbonatable materials and porosity of concrete. Furthermore, carbonation depth was calculated by considering both concrete chemical components and environmental conditions.

Regarding the life cycle assessment of $\mathrm{CO}_{2}$ emission, Hasanbeigi [10], Gartner [11], Miller [12], Roh [13], Kim [14], and Tae [15,16] analyzed carbon dioxide emissions for buildings with different concrete mixing proportions, different building types, and different life cycle stages. On the other hand, some numerical algorithms have been proposed to make an optimum design regarding the reduction of carbon dioxide emission. Using the evolution algorithm, Kim [17] and Roh [18] selected the optimal concrete mix design method, which minimizes the $\mathrm{CO}_{2}$ emission of an apartment house. Ji [19] proposed three methods (eco-efficiency, environmental priority strategy system, and certified emissions reduction price) to support the decision-making processes that simultaneously consider cost and $\mathrm{CO}_{2}$ emissions. Yepes [20] proposed a hybrid glowworm swarm algorithm and optimized the cost and $\mathrm{CO}_{2}$ emissions of concrete beam roads.

However, the carbon dioxide uptake from carbonation was not considered in References [3-20]. Carbonation is a lengthy chemical reaction process and will proceed continuously during the service life of buildings. Carbon dioxide will be absorbed into concrete due to carbonation. Compared with abundant research regarding carbonation and the carbon dioxide emission life cycle [3-20], the study of carbon dioxide uptake is relatively limited. In recent years, References [21-25] presented some analysis models of the carbon dioxide uptake from carbonation.

Using the carbonation reaction model, Lee [21] analyzed carbon dioxide uptake due to carbonation in the building use stage. García-Segura [22] made life cycle greenhouse gas emissions of blended cement concrete, considering carbonation and durability. The carbon dioxide uptake due to carbonation during the use stage and after demolition stage was considered.

However, in Lee's [21], García-Segura's [22], and other researchers' [3-20] studies, they assumed that cement is completely hydrated (i.e., the hydration degree is $100 \%$ ) regardless of the water to cement ratio. Lagerblad [23] and Yang [24] reported that concrete with lower water to cement ratios has a slower rate of hydration and a lower ultimate degree of hydration. Yang [24] proposed a Portland cement hydration model, evaluated the contents of carbonatable materials, and calculated carbonation depth and carbon dioxide uptake during the use stage and recycling of demolished concrete. Kashef-Haghighi [25] proposed a mathematical model, evaluated the hydration degree of Portland cement, and calculated carbon dioxide uptake in accelerated carbonation curing.

However, the hydration model proposed by Yang [24] and Kashef-Haghighi [25] is only valid for Portland cement. For slag-blended cement, due to the coexistence of cement hydration and slag reaction, Yang's [24] or Kashef-Haghighi's [25] hydration model is not valid.

In this study, to overcome the weak points in former studies [3-25], we propose a slag-blended cement hydration model, calculate carbonatable materials' content and porosity, and evaluate carbonation depth and carbon dioxide uptake. The flowchart of the proposed numerical procedure is shown in Figure 1. The input parameters of the numerical procedure are the shopping drawing of buildings and environmental conditions. By using shopping drawings, the total volume and surface 
area of concrete are calculated. By using the total volume of concrete and unit carbon dioxide emission of materials, carbon dioxide emissions are calculated. Then, by using a carbonation model considering material properties and environmental conditions, the carbonation depth is determined. By using the carbonation depth of concrete, the surface area of concrete structures, and the amount of carbonatable materials, the absorbed carbon dioxide is calculated. Finally, the ratio between mass of absorbed $\mathrm{CO}_{2}$ and mass of emitted $\mathrm{CO}_{2}$ is calculated.

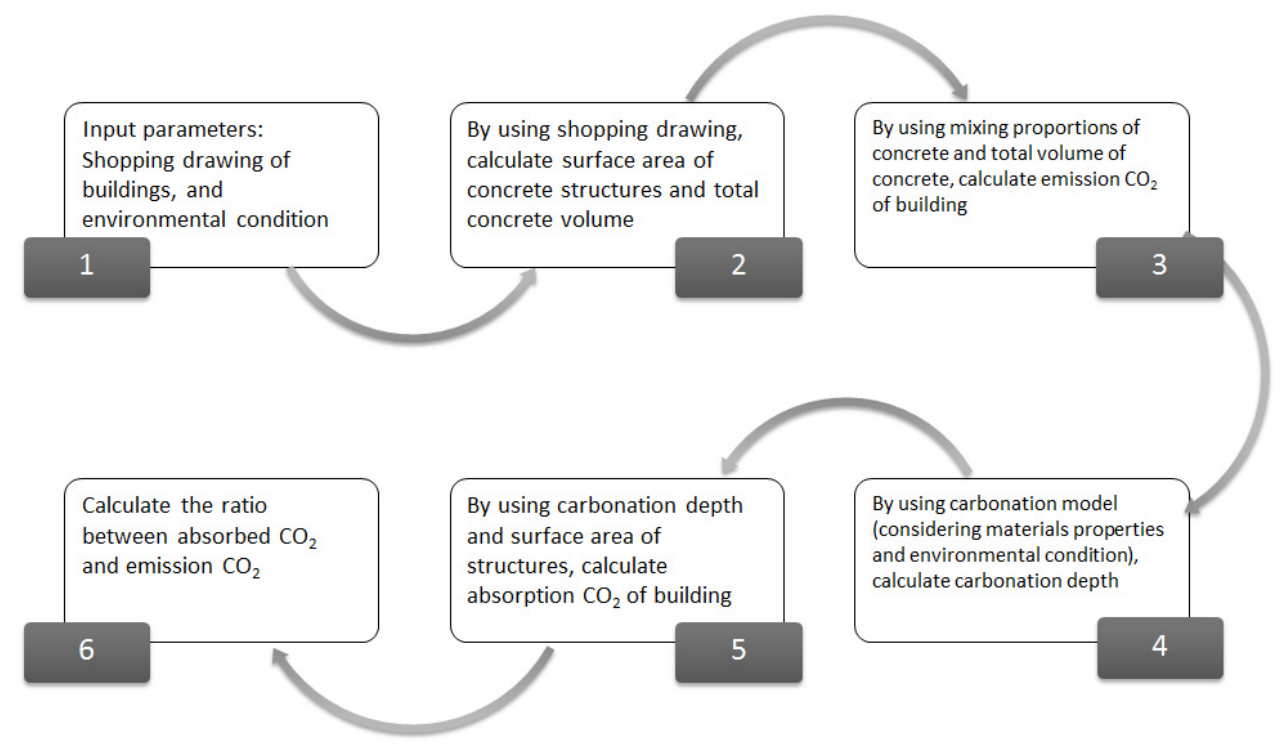

Figure 1. Flowchart of numerical process.

The contributions of this article are summarized as follows: first, propose a slag-blended cement hydration model and calculate reaction degrees of cement and slag. Second, evaluate the carbonatable materials content and porosity using the reaction degrees of binders. Third, calculate carbonation depth and carbon dioxide uptake of slag-blended concrete, considering material properties and environmental conditions.

\section{Evaluation of $\mathrm{CO}_{2}$ Emissions and $\mathrm{CO}_{2}$ Uptake of Slag-Blended Concrete}

\section{1. $\mathrm{CO}_{2}$ Emissions}

Emissions of $\mathrm{CO}_{2}$ from Portland cement production include direct emissions and indirect emissions. As shown in Table 1, direct $\mathrm{CO}_{2}$ emissions mainly come from carbonate decomposition from raw material and the burning of cement kiln fuel. Indirect $\mathrm{CO}_{2}$ emissions mainly come from electricity consumption. Considering both direct and indirect $\mathrm{CO}_{2}$ emissions, to produce 1 ton of ordinary Portland cement, 0.93 ton of $\mathrm{CO}_{2}$ will be emitted [1].

Table 1. Emission factor of $\mathrm{CO}_{2}$ in Portland cement production process [1].

\begin{tabular}{clc}
\hline Emission Relationship & \multicolumn{1}{c}{ Emission Style } & $\mathbf{C O}_{\mathbf{2}}$ Emission Factor (t/t) \\
\hline \multirow{3}{*}{ Direct emission } & Carbonate decomposition from raw material & 0.527 \\
& Kiln dust calcining & 0.009 \\
& Organic carbon burning of raw material & 0.012 \\
& Burning of cement kiln fuel & 0.235 \\
\hline \multirow{2}{*}{ Indirect emission } & Cement clinker electricity consumption & 0.15 \\
& Cement flour electricity consumption & \\
\hline
\end{tabular}

During the production of concrete, cement, water, aggregate, mineral admixtures, and superplasticizer will be used. Table 2 shows a summary of $\mathrm{CO}_{2}$ emission factors for concrete production. 
The $\mathrm{CO}_{2}$ emission content of $1 \mathrm{~kg}$ of GGBFS is $0.034 \mathrm{~kg}$ [1], which is much lower than that of ordinary Portland cement. The $\mathrm{CO}_{2}$ emission from concrete production can be calculated as follows:

$$
\mathrm{CO}_{2}-e=\mathrm{CO}_{2}-e_{\mathrm{M}}+\mathrm{CO}_{2}-e_{T}+\mathrm{CO}_{2}-e_{P},
$$

where $\mathrm{CO}_{2}$-e is the total $\mathrm{CO}_{2}$ emission from concrete production, $\mathrm{CO}_{2}-\mathrm{e}_{\mathrm{M}}$ is the emission of $\mathrm{CO}_{2}$ from concrete materials, $\mathrm{CO}_{2}-\mathrm{e}_{\mathrm{T}}$ is the emission of $\mathrm{CO}_{2}$ from transport, and $\mathrm{CO}_{2}-\mathrm{e}_{\mathrm{P}}$ is the emission of $\mathrm{CO}_{2}$ from the mixing of concrete. $\mathrm{CO}_{2}-\mathrm{e}_{\mathrm{M}}$ is the sum of $\mathrm{CO}_{2}$ emissions from various components of concrete, such as $\mathrm{CO}_{2}$ emissions from producing cement, water, fine aggregate, coarse aggregate, mineral admixtures, and superplasticizer. Table 3 shows an example of $\mathrm{CO}_{2}$ emissions during the concrete production process. The input parameters are concrete mixing proportions, the $\mathrm{CO}_{2}$ emissions factor, the transportation cycle, and distance. The output result is total $\mathrm{CO}_{2}$ emissions from the concrete production process.

Table 2. Summary of $\mathrm{CO}_{2}$ emissions for concrete production [1].

\begin{tabular}{cccccccc}
\hline OPC & GGBFS & Sand & Gravel & Water & SuperplasticizerTruck & $\begin{array}{c}\text { Concrete } \\
\text { Mixing }\end{array}$ \\
\hline $\begin{array}{c}9.31 \times 10^{-1} \\
(\mathrm{~kg} / \mathrm{kg})\end{array}$ & $\begin{array}{c}3.40 \times 10^{-2} \\
(\mathrm{~kg} / \mathrm{kg})\end{array}$ & $\begin{array}{c}0.0037 \\
(\mathrm{~kg} / \mathrm{kg})\end{array}$ & $\begin{array}{c}0.0028 \\
(\mathrm{~kg} / \mathrm{kg})\end{array}$ & $\begin{array}{c}1.12 \times 10^{-4} \\
(\mathrm{~kg} / \mathrm{kg})\end{array}$ & $\begin{array}{c}0.25 \\
(\mathrm{~kg} / \mathrm{kg})\end{array}$ & $\begin{array}{c}3 \times 10^{-5} \\
(\mathrm{~kg} / \mathrm{kg} \cdot \mathrm{km})\end{array}$ & $\begin{array}{c}0.007 \\
\left(\mathrm{~kg} / \mathrm{m}^{3}\right)\end{array}$ \\
\hline
\end{tabular}

Table 3. Example of $\mathrm{CO}_{2}$ emissions during the concrete production process.

\begin{tabular}{|c|c|c|c|c|c|c|}
\hline & \multicolumn{3}{|c|}{ Material } & \multicolumn{3}{|c|}{ Transport } \\
\hline Unit & A & B & $\mathbf{C}=\mathbf{A} \times \mathbf{B}$ & D & E & $\mathbf{F}=\mathbf{A} \times \mathbf{D} \times \mathbf{E}$ \\
\hline Item & kg & $\mathrm{CO}_{2} \mathrm{~kg} / \mathrm{kg}$ & kg & $\mathrm{km}$ & $\mathrm{CO}_{2} \mathrm{~kg} / \mathrm{kg} \cdot \mathrm{km}$ & kg \\
\hline OPC & 300 & 0.931 & 279.3 & 25 & $3.00 \times 10^{-5}$ & 0.225 \\
\hline Sand & 890 & 0.0037 & 3.293 & 15 & $3.00 \times 10^{-5}$ & 0.401 \\
\hline Gravel & 970 & 0.0028 & 2.716 & 15 & $3.00 \times 10^{-5}$ & 0.436 \\
\hline Water & 150 & $1.12 \times 10^{-4}$ & 0.0168 & - & - & - \\
\hline \multicolumn{3}{|c|}{ sum } & 285.33 & \multicolumn{2}{|r|}{ sum } & 1.062 \\
\hline Concrete mixing & $1 \mathrm{~m}^{3}$ & $0.71 \mathrm{~kg} / \mathrm{m}^{3}$ & 0.71 & & & \\
\hline Total & & & $287.102=$ & $33+1$ & +0.71 & \\
\hline
\end{tabular}

\section{2. $\mathrm{CO}_{2}$ Uptake from Carbonation of Concrete}

Carbon dioxide will be absorbed into concrete due to carbonation. Concrete carbonation is a complicated physicochemical process. The process consists of several steps, such as the diffusion of gaseous phase $\mathrm{CO}_{2}$ from the air environment into concrete pores, $\mathrm{CO}_{2}$ dissolution in the water film of concrete pores, the dissolution of solid calcium hydroxide $(\mathrm{CH})$ in concrete pore water, the diffusion of dissolved $\mathrm{CH}$ in concrete pore water, $\mathrm{CH}$ reaction with dissolved $\mathrm{CO}_{2}$, and the reaction of $\mathrm{CO}_{2}$ with calcium silicate hydrate (CSH). The chemical reaction of carbonation is shown as follows:

$$
\begin{gathered}
\mathrm{Ca}(\mathrm{OH})_{2}+\mathrm{CO}_{2} \rightarrow \mathrm{CaCO}_{3}+\mathrm{H}_{2} \mathrm{O} \\
\left(3 \mathrm{CaO} \cdot 2 \mathrm{SiO}_{2} \cdot 3 \mathrm{H}_{2} \mathrm{O}\right)+3 \mathrm{CO}_{2} \rightarrow 3 \mathrm{CaCO}_{3} \cdot 2 \mathrm{SiO}_{2} \cdot 3 \mathrm{H}_{2} \mathrm{O} .
\end{gathered}
$$

As shown in Equations (2) and (3), carbonation closely relates to the compound compositions of concrete, such as the amount of carbonatable materials $\mathrm{CH}$ and $\mathrm{CSH}$. Moreover, carbonation also relates to the concrete porosity because concrete pores are necessary paths for the diffusion of atmospheric $\mathrm{CO}_{2}$ into the concrete. Hence, to evaluate concrete carbonation depth, an accurate evaluation of the concrete material properties is necessary, such as $\mathrm{CH}$ content, $\mathrm{CSH}$ content, and porosity.

Concrete material properties closely relate to mixing proportions and the hydration process. Our former research $[26,27]$ originally proposed a blended hydration model for slag-blended concrete. 
The hydration model starts with concrete mixing proportions. The age-dependent material properties of concrete, such as the carbonatable materials content and porosity, can be quantitatively calculated. The hydration model has a wide application range for concrete, with different water to binder ratios, different slag replacement levels, and different curing methods [26,27].

In our proposed hydration model, the hydration degree of cement and reaction degree of slag are adopted as fundamental indicators to evaluate properties of hardening slag-blended concrete. The hydration degree of cement $(\alpha)$ is defined as the ratio of the mass of hydrated cement to the mass of cement in the mixing proportion. The value of the hydration degree of cement $(\alpha)$ ranges between 0 and 1. $\alpha=0$ means cement hydration does not start and $\alpha=1$ means all the cement has been hydrated. The hydration degree of cement can be determined using an integration method in the time domain $\left(\alpha=\int_{0}^{t}\left(\frac{d \alpha}{d t}\right) d t\right.$, where $t$ is time; $\frac{d \alpha}{d t}$ is the rate of cement hydration. The detailed equation for $\frac{d \alpha}{d t}$ is available in our former research $\left.[26,27]\right)$. Similarly, the reaction degree of slag $\left(\alpha_{S G}\right)$ is defined as the ratio of the mass of reacted slag to the mass of slag in the mixing proportion. The value of the reaction degree of slag $\left(\alpha_{S G}\right)$ ranges between 0 and $1 . \alpha_{S G}=0$ means the slag reaction does not start and $\alpha_{S G}=1$ means all the slag has reacted. The reaction degree of slag can also be determined using an integration method in the time domain $\left(\alpha_{S G}=\int_{0}^{t}\left(\frac{d \alpha_{S G}}{d t}\right) d t\right.$, where $\frac{d \alpha_{S G}}{d t}$ is the rate of the slag reaction. The detailed equation for $\frac{d \alpha_{S G}}{d t}$ is available in our former research [26,27]).

For slag-blended concrete, calcium hydroxide and calcium silicate hydrate are carbonatable materials. Cement hydration produces calcium hydroxide, while the slag reaction consumes calcium hydroxide. Considering the production and consumption of calcium hydroxide, the amounts of calcium hydroxide in cement-slag can be determined as follows [26,27]:

$$
C H(t)=R C H_{C E} \times C_{0} \times \alpha-v_{S G} \times \alpha_{S G} \times P,
$$

where $\mathrm{RCH}_{C E}$ denotes the mass of calcium hydroxide produced by 1-unit mass cement hydration; $C_{0}$ is the mass of cement; $\alpha$ denotes the degree of cement hydration; $v_{S G}$ denotes the stoichiometric ratio of the mass of $\mathrm{CH}$ to slag $\left(v_{S G}=0.22[28,29]\right) ; \alpha_{S G}$ denotes the degree of reaction of slag; and $P$ is the mass of mineral mixtures. $R C H_{C E} \times C_{0} \times \alpha$ considers the production of calcium hydroxide from cement hydration, while $v_{S G} \times \alpha_{S G} \times P$ considers the consumption of calcium hydroxide from the slag reaction.

For slag-blended concrete, the calcium silicate hydrate (CSH) content, which is the most critical parameter to strength development, can be calculated as a function of the binder content, reaction degree of binders, the weight fraction of reactive silica in slag, and the weight fractions of the $\mathrm{SiO}_{2}$ in the slag and cement. The amount of CSH in hardening slag-blended concrete can be calculated as follows [26,27]:

$$
\operatorname{CSH}(t)=2.85\left(f_{S, C} \times C_{0} \times \alpha+\gamma_{S} \times f_{S, P} \times P \times \alpha_{S G}\right),
$$

where $f_{S, C}$ is the weight fraction of silica in cement and $f_{S, P}$ is the weight fraction of silica in slag; and $\gamma_{S}$ is the weight fraction of the reactive $\mathrm{SiO}_{2}$ in the slag. The coefficient 2.85 is the mass ratio between the molar weight of $\mathrm{CSH}$ and the weight of oxide $\mathrm{SiO}_{2}$ in $\mathrm{CSH} . f_{S, C} \times \mathrm{C}_{0} \times \alpha$ considers the $\mathrm{CSH}$ production from cement hydration, while $\gamma_{S} \times f_{S, P} \times P \times \alpha_{S G}$ considers the CSH production from the slag reaction.

The porosity of hydrating blends is reduced due to the Portland cement hydration, reaction of slag, and carbonation of concrete. The porosity, $\varepsilon$, can be estimated as follows [26,27]:

$$
\varepsilon(t)=\frac{W}{\rho_{W}}-0.25 \times C_{0} \times \alpha-0.3 \times \alpha_{S G} \times P-\Delta \varepsilon_{C},
$$


where $\varepsilon$ is porosity, $W$ is water content, and $\rho_{W}$ is the density of water. $0.25 \times C_{0} \times \alpha$ considers the porosity reduction from cement hydration, while $0.3 \times \alpha_{S G} \times P$ considers the porosity reduction from the slag reaction; $\Delta \varepsilon_{C}$ is the reduction of porosity due to the carbonation of concrete.

The calculation results from Equations (4)-(6) can used as input parameters for carbonation depth calculation models. For the usual range of parameters (especially for relative humidity higher than $55 \%$, where $\mathrm{CO}_{2}$ diffusion controls the carbonation process [8,9]), a carbonation front will take place that distinguishes concrete as one of two different parts: a fully carbonated part and one part in which concrete carbonation has not started at all. The distance between this carbonation front and the outer concrete surface is called the carbonation depth, and for the most common one-dimensional cases, its evolution with time is given by a simple analytical expression, in terms of the composition and the environmental conditions. The evolution of concrete carbonation depth $x_{c}$ with time $t$ is calculated as follows $[8,9,26,27]$ :

$$
\begin{gathered}
x_{c}=\sqrt{\frac{2 D_{C}\left[\mathrm{CO}_{2}\right]_{0} t}{0.33 \mathrm{CH}+0.214 \mathrm{CSH}}} \\
D_{C}=A\left(\frac{\varepsilon}{\frac{\varepsilon}{\rho_{0}}+\frac{P}{\rho_{S G}}+\frac{W_{0}}{\rho_{w}}}\right)^{a}\left(1-\frac{R H}{100}\right)^{2.2},
\end{gathered}
$$

where $\left[\mathrm{CO}_{2}\right]_{0}$ is the ambient concentration of $\mathrm{CO}_{2}$ at the concrete surface and $A$ and $a$ are reaction parameters. $0.33 \mathrm{CH}+0.214 \mathrm{CSH}$ in the denominator of Equation (7) denotes the $\mathrm{CO}_{2}$ uptake ability of concrete. $\mathrm{RH}$ in Equation (8) is the ambient relative humidity (because carbonation generally occurs at the surface region of concrete, Papadakis [8,9] assumed that the relative humidity in the carbonated zone is equal to that in the ambient environment). The effect of relative humidity on the rate of hydration can be considered using a reduction factor $\beta_{R H}=\left[\frac{R H-0.55}{0.45}\right]^{4}$ for $\mathrm{RH}>0.55$ and $\beta_{R H}=0$ for $\mathrm{RH}<0.55[26,27,30,31])$. In Equations (4)-(6), to consider the further hydration of binders during the concrete carbonation period, items $\alpha$ and $\alpha_{S G}$ should be multiplied by $\beta_{\mathrm{RH}}$. The influence of temperature on carbonation depth can be considered using the activation energy $[8,9,26,27,32-36]$.

The $\mathrm{CO}_{2}$ uptake due to concrete carbonation can be determined as follows:

$$
\mathrm{CO}_{2}-u=x_{c} \times S \times(0.33 \mathrm{CH}+0.214 \mathrm{CSH}),
$$

where $\mathrm{CO}_{2}-u$ is the $\mathrm{CO}_{2}$ uptake due to carbonation and $S$ is the surface area of the building. In Equation (9), the unit of $x_{c}$ is $\mathrm{m}$, the unit of $S$ is $\mathrm{m}^{2}$, and the unit of carbonatable materials $\mathrm{CH}$ and $\mathrm{CSH}$ is $\mathrm{kg} / \mathrm{m}^{3}$; hence, the unit of $\mathrm{CO}_{2}-u$ is $\mathrm{kg}\left(\mathrm{m} \times \mathrm{m}^{2} \times \mathrm{kg} / \mathrm{m}^{3}=\mathrm{kg}\right)$.

The $\mathrm{CO}_{2}$ uptake ratio $\chi$ due to carbonation can be calculated as follows:

$$
x=\frac{\mathrm{CO}_{2}-u}{\mathrm{CO}_{2}-e} .
$$

The calculation steps for determining the $\mathrm{CO}_{2}$ uptake ratio are summarized as follows:

(1) Using building scales and shopping drawings, calculate the total volume and surface area of concrete. The carbon dioxide emissions are calculated using the total volume of concrete and unit carbon dioxide emission of materials (Equation (1)).

(2) Using the blended cement hydration model, calculate carbonatable materials content and the porosity of concrete (Equations (4)-(6)).

(3) Using the carbonation model, calculate the carbonation depth of concrete (Equations (7) and (8)).

(4) Using the $\mathrm{CO}_{2}$ uptake model, calculate the content of $\mathrm{CO}_{2}$ uptake due to carbonation (Equation (9)).

(5) Based on $\mathrm{CO}_{2}$ emission content and $\mathrm{CO}_{2}$ uptake content, calculate the $\mathrm{CO}_{2}$ uptake ratio due to carbonation (Equation (10)). 


\section{Experimental Study of Accelerated Carbonation of Slag-Blended Concrete}

Accelerated carbonation tests are widely used to evaluate the carbonation durability of concrete. The $\mathrm{CO}_{2}$ concentration employed in accelerated carbonation tests is much higher than that in the natural environment. Papadakis [8,9] compared the carbonation of concrete under both a natural environment $\left(0.03 \% \mathrm{CO}_{2}\right.$ by volume) and accelerated carbonation tests $\left(7 \%\right.$ and $50 \% \mathrm{CO}_{2}$ by volume). Papadakis [8,9] found that Equation (7) is valid for concrete with different $\mathrm{CO}_{2}$ concentrations. Because the effect of $\mathrm{CO}_{2}$ concentration on carbonation is considered in Equation (7), the coefficients in Equation (7) do not vary with $\mathrm{CO}_{2}$ concentration.

To verify the carbonation model, a laboratory experimental study was carried out on accelerated carbonation tests of slag-blended concrete with different water to binder ratios (0.3 and 0.5) and slag replacement levels $(30 \%$ and $50 \%)$. The compound compositions of cement and slag are shown in Table 4. The mixing proportions of concrete are shown in Table 5. The size of prism specimens is $10 \mathrm{~cm} \times 10 \mathrm{~cm} \times 40 \mathrm{~cm}$. After 28 days of sealed curing, the specimens were put into a carbonation chamber, in which the $\mathrm{CO}_{2}$ concentration was much higher than that of the natural environment. During accelerated carbonation tests, five sides of prism specimens were sealed with epoxy and one side of each specimen was exposed to $\mathrm{CO}_{2}$. Hence, one-dimensional $\mathrm{CO}_{2}$ ingression occurred. The temperature in the carbonation chamber was $20^{\circ} \mathrm{C}$, the relative humidity in the carbonation chamber was $60 \%$, and the $\mathrm{CO}_{2}$ concentration in the carbonation chamber was $10 \%$. After $1,4,8,13$, and 26 weeks of exposure, the carbonation depth was measured via phenolphthalein spraying.

Table 4. Chemical compositions and physical properties of binder materials.

\begin{tabular}{cccc}
\hline Used Materials & & OPC & GGBFS \\
\hline & $\mathrm{SiO}_{2}$ & 19.29 & 35.1 \\
& $\mathrm{Al}_{2} \mathrm{O}_{3}$ & 5.16 & 15.02 \\
& $\mathrm{Fe}_{2} \mathrm{O}_{3}$ & 2.87 & 0.53 \\
& $\mathrm{CaO}$ & 61.68 & 43.0 \\
Chemical compositions (\%) & $\mathrm{MgO}$ & 4.17 & 5.59 \\
& $\mathrm{SO}_{3}$ & 2.53 & 0.06 \\
& $\mathrm{~K}_{2} \mathrm{O}$ & 0.92 & 0.28 \\
& $\mathrm{Na}_{2} \mathrm{O}$ & 0.205 & 0.24 \\
\hline \multirow{3}{*}{ Physical properties } & Fineness (cm $\left.{ }^{2} / \mathrm{g}\right)$ & 3200 & 4500 \\
& Specific gravity & 3.15 & 2.9 \\
& Loss on ignition & 1.49 & 0.02 \\
\hline
\end{tabular}

Table 5. Mix proportions of concrete.

\begin{tabular}{|c|c|c|c|c|c|c|c|c|}
\hline \multirow{2}{*}{ Specimens } & \multicolumn{8}{|c|}{ Unit Weight $\left(\mathrm{kg} / \mathrm{m}^{3}\right)$} \\
\hline & $\begin{array}{c}\text { Water to Binder } \\
\text { Ratio }\end{array}$ & $\begin{array}{c}\text { Slag Replacement } \\
\text { Levels }\end{array}$ & Water & OPC & GGBFS & Sand & Gravel & $\begin{array}{c}\text { Superplasticizer } \\
(\%)\end{array}$ \\
\hline $0.5 S 0$ & 0.5 & 0 & 174 & 344 & 0 & 811 & 941 & 0.68 \\
\hline $0.5 \mathrm{~S} 30$ & 0.5 & $30 \%$ & 174 & 241 & 103 & 811 & 941 & 0.68 \\
\hline $0.5 S 50$ & 0.5 & $50 \%$ & 174 & 172 & 172 & 811 & 941 & 0.68 \\
\hline $0.3 \mathrm{~S} 0$ & 0.3 & 0 & 154 & 514 & 0 & 752 & 845 & 4.11 \\
\hline $0.3 S 30$ & 0.3 & $30 \%$ & 154 & 360 & 154 & 752 & 845 & 4.11 \\
\hline 0.3550 & 0.3 & $50 \%$ & 154 & 257 & 257 & 752 & 845 & 4.11 \\
\hline
\end{tabular}

Figure 2 shows the reaction degree of cement $(\alpha)$ in cement-slag blends. For slag-blended concrete, the addition of slag will improve the water to cement ratio. Consequently, the reaction degree of cement in cement-slag blends is higher than in plain cement specimens [26-31]. The more slag additions, the higher the cement hydration degree. With a lower water to binder ratio (Figure 2b), a higher replacement of slag will increase the hydration degree of the cement.

Figure 3 shows the reaction degree of slag $\left(\alpha_{S G}\right)$ in cement-slag blends. When the replacement ratio of slag increases from $30 \%$ to $50 \%$, the alkali-activated effect on the slag reaction will be weakened and the reaction degree of slag will decrease. When the water to binder ratio decreases from 0.5 
(Figure 3a) to 0.3 (Figure 3b), due to the reduction of the capillary water concentration and available deposit space of reaction products, the reaction degree of the slag will decrease [26-31].

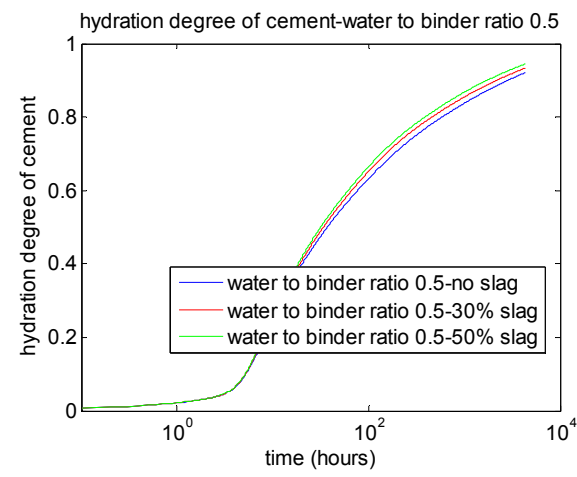

(a)

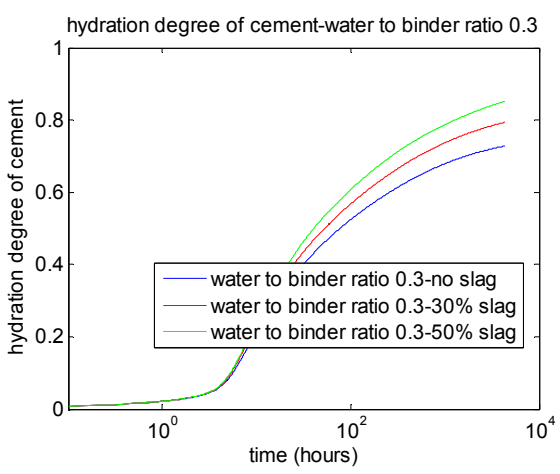

(b)

Figure 2. Reaction degree of cement. (a) Water to binder ratio of 0.5 ; (b) water to binder ratio of 0.3 .

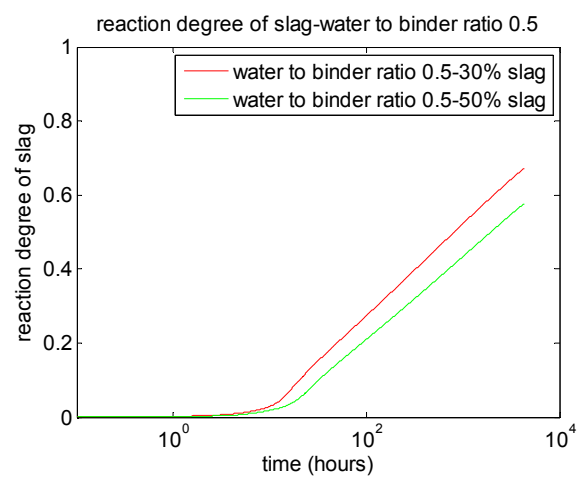

(a)

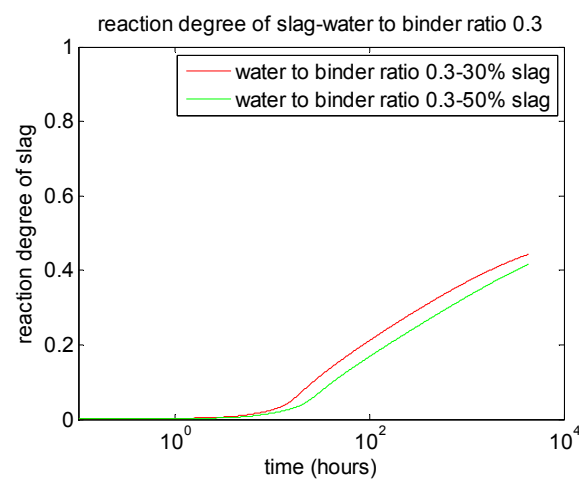

(b)

Figure 3. Reaction degree of slag. (a) Water to binder ratio of 0.5 ; (b) water to binder ratio of 0.3 .

Using the concrete mixing proportions and reaction degrees of cement and slag, the calcium hydroxide $(\mathrm{CH})$ contents can be calculated using Equation (4). As shown in Figure 4, for slag-blended concrete, due to the consumption of $\mathrm{CH}$ from the slag reaction, the $\mathrm{CH}$ content of slag-blended concrete is much lower than that of the control concrete. When slag replacement levels increase, $\mathrm{CH}$ content will decrease. When the water to binder ratio decreases from 0.5 (Figure 4a) to 0.3 (Figure $4 b$ ), the $\mathrm{CH}$ contents will increase [26-31].

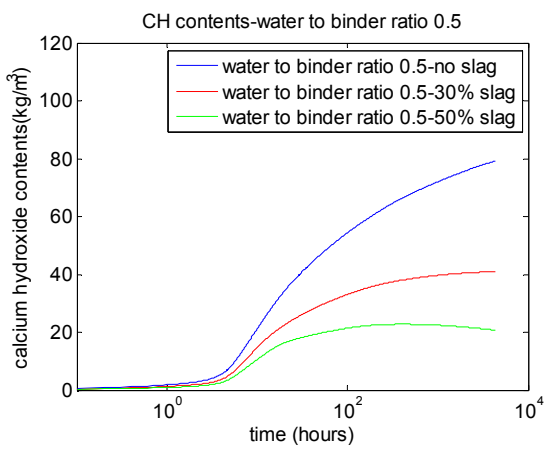

(a)

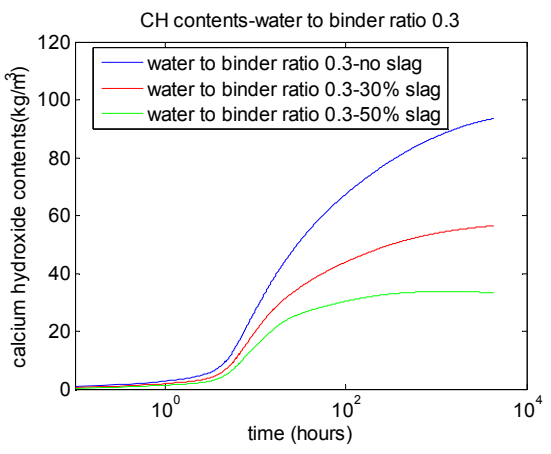

(b)

Figure 4. Calcium hydroxide $(\mathrm{CH})$ contents. (a) Water to binder ratio of 0.5 ; (b) water to binder ratio of 0.3 . 
Using the concrete mixing proportions and reaction degrees of cement and slag, calcium silicate hydrate (CSH) contents can be calculated by using Equation (5). As shown in Figure 5, for slag-blended concrete, in early stages, mainly because the reaction degree of slag is lower than that of cement, the CSH contents of slag-blended concrete are lower than those of the control concrete. At a late stage, mainly because the $\mathrm{SiO}_{2}$ content in the slag is higher than that in OPC, the CSH contents of slag-blended concrete can surpass those of the control concrete. When slag replacement levels increase, the time corresponding to strength surpassing will delay. When the water to binder ratio decreases from 0.5 (Figure 5a) to 0.3 (Figure 5b), the CSH contents will increase [26-31].

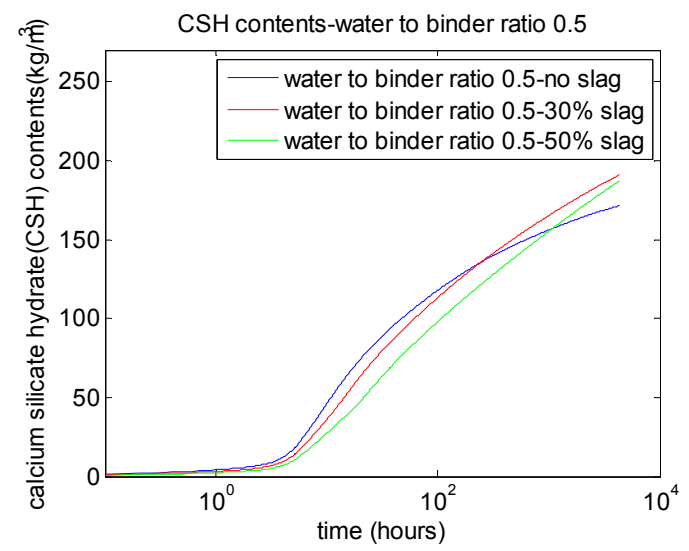

(a)

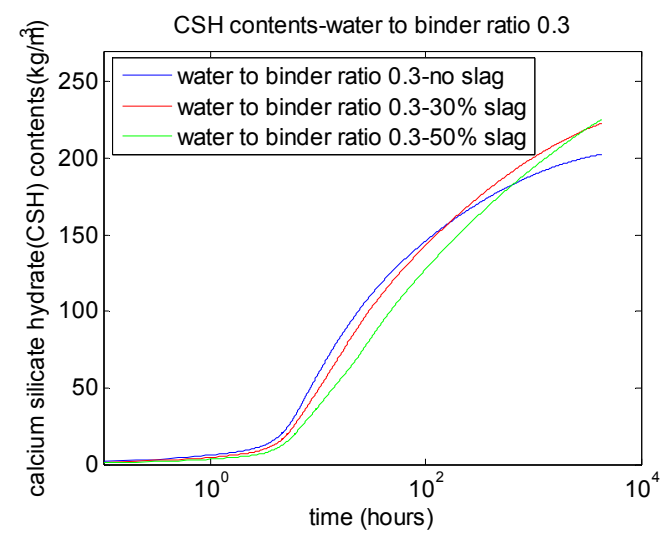

(b)

Figure 5. Calcium silicate hydrate (CSH) contents. (a) Water to binder ratio of 0.5 ; (b) water to binder ratio of 0.3 .

Using the concrete mixing proportions and reaction degrees of OPC and GGBFS, porosity reduction in paste due to the hydration of binders can be calculated using Equation (6). As shown in Figure 6, for OPC-slag blends, because the reaction rate of slag is slower than that of OPC, the porosity of slag blended paste is higher than that of the control paste. When the water to binder ratio decreases from 0.5 (Figure 6a) to 0.3 (Figure 6b), the porosity will decrease [26-31].

After determination of the carbonatable materials content and porosity of concrete, the carbonation depth of concrete can be calculated using Equation (7) $\left(A=6.5 \times 10^{-6}\right.$ and $\left.a=3.6\right)$. Figure 7 shows experimental $v s$. analytical results. The analysis results generally agree with the experimental results. When the slag replacement levels increase, the carbonation depth increases and more $\mathrm{CO}_{2}$ is absorbed into the concrete. When the water to binder ratio decreases from 0.5 (Figure 7a) to 0.3 (Figure 7b), the carbonation depth of concrete decreases significantly [26-31].

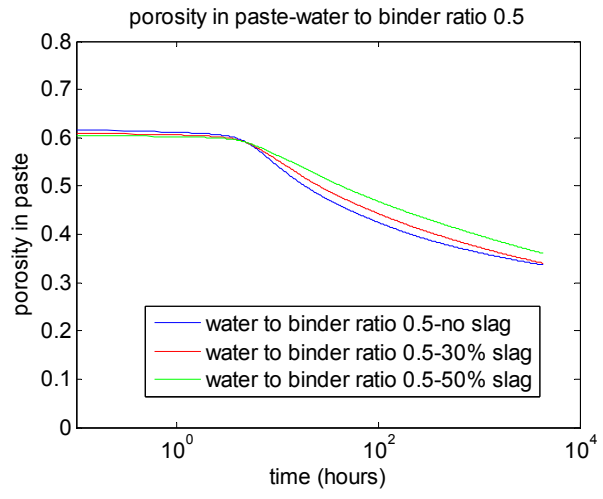

(a)

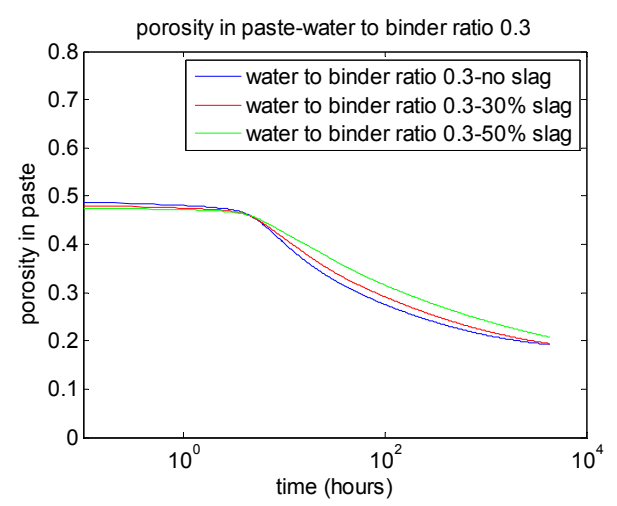

(b)

Figure 6. Porosity in paste. (a) Water to binder ratio of 0.5 ; (b) water to binder ratio of 0.3 . 


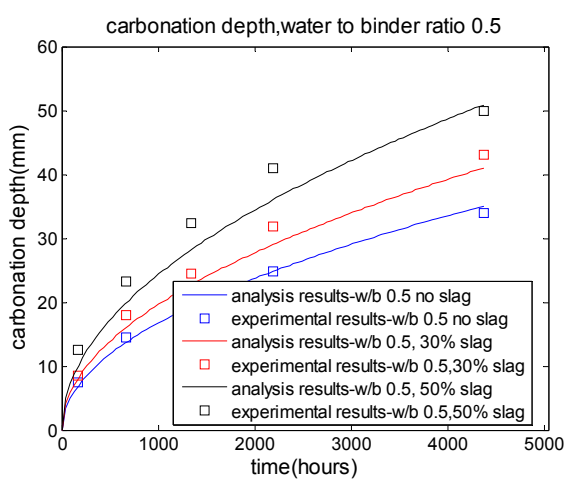

(a)

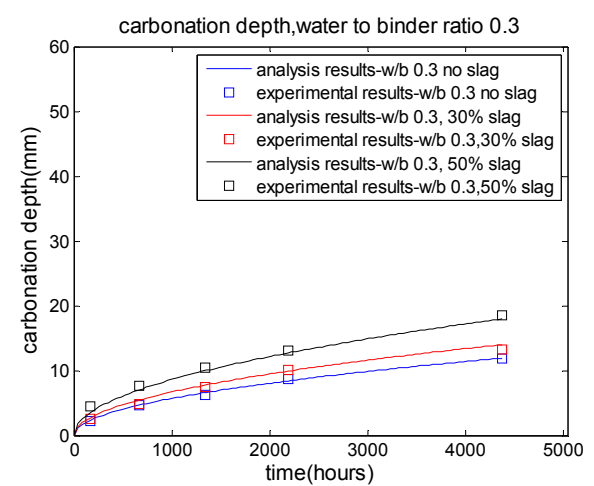

(b)

Figure 7. Carbonation depth of concrete. (a) Water to binder ratio of 0.5 ; (b) water to binder ratio of 0.3 .

\section{4. $\mathrm{CO}_{2}$ Uptake in Real Buildings}

\subsection{Effect of Finishing Materials and Cracks on Carbonation}

For calculating carbonation depth, Equation (7) is valid for sound concrete without cracks or finishing materials. For concrete in real buildings, due to loading and environmental effects, cracks frequently occur. The diffusivity of $\mathrm{CO}_{2}$ in air is much higher than that in concrete and surface cracks will aggravate carbonation [32]. On the other hand, finishing materials, such as mortar and waterproof coatings, are widely used to improve the durability performance of concrete structures [33-36]. Considering the effects of cracks and finishing materials, the calculation equation for carbonation depth in concrete can be modified as follows [33-36]:

$$
x_{c}^{\prime}=\beta_{c r} \times \beta_{f m} \times x_{c},
$$

where $x_{c}^{\prime}$ is the carbonation depth considering the effects of cracks and finishing materials and $\beta_{c r}$ considers the aggravation effect of cracks on carbonation. $\beta_{c r}$ is higher than 1.0 and relates to crack characteristics such as crack width, crack depth, and crack spacing distance [32]. $\beta_{f m}$ considers the suppression effect of finishing materials on carbonation. $\beta_{f m}$ is lower than 1.0 and relates to characteristics of finishing materials, such as material type, depth of finishing materials, and environment influence [33-36]. Yoda [35] conducted field investigations of the carbonation of slag-blended concrete via 40 years of natural aging and the preventive effect of finishing materials. Yoda [35] found that the carbonation suppression coefficients $\beta_{f m}$ for $20 \mathrm{~mm}$ mortar, $5 \mathrm{~mm}$ coating, and tile are $0.166,0.4$, and 0.1, respectively. On the other hand, note that Equation (11) is an empirical equation. Equation (11) does not accurately simulate the diffusion and carbonation reaction process. The effect of covering materials on carbonation should be further studied. First, $\mathrm{CO}_{2}$ diffusivity in covering materials and the chemical reaction between covering materials and $\mathrm{CO}_{2}$ should be measured. Second, the diffusion-reaction process in cover materials and substrate concrete should be modeled. Third, the continuity conditions on the interface between cover materials and substrate concrete should be established.

\section{2. $\mathrm{CO}_{2}$ Uptake in Real Buildings during Use Stage}

In this study, a 30-story apartment complex was selected to evaluate the $\mathrm{CO}_{2}$ absorption of concrete. The 1st floor to 3rd floor are a shopping mall and the 4th floor to 30th floor are for residual usage. The building floor plan (scale $=1 / 500$ ) is shown in Figure 8 and the building elevation plan is shown in Figure 9. The structure type is a frame-shear wall structure. 


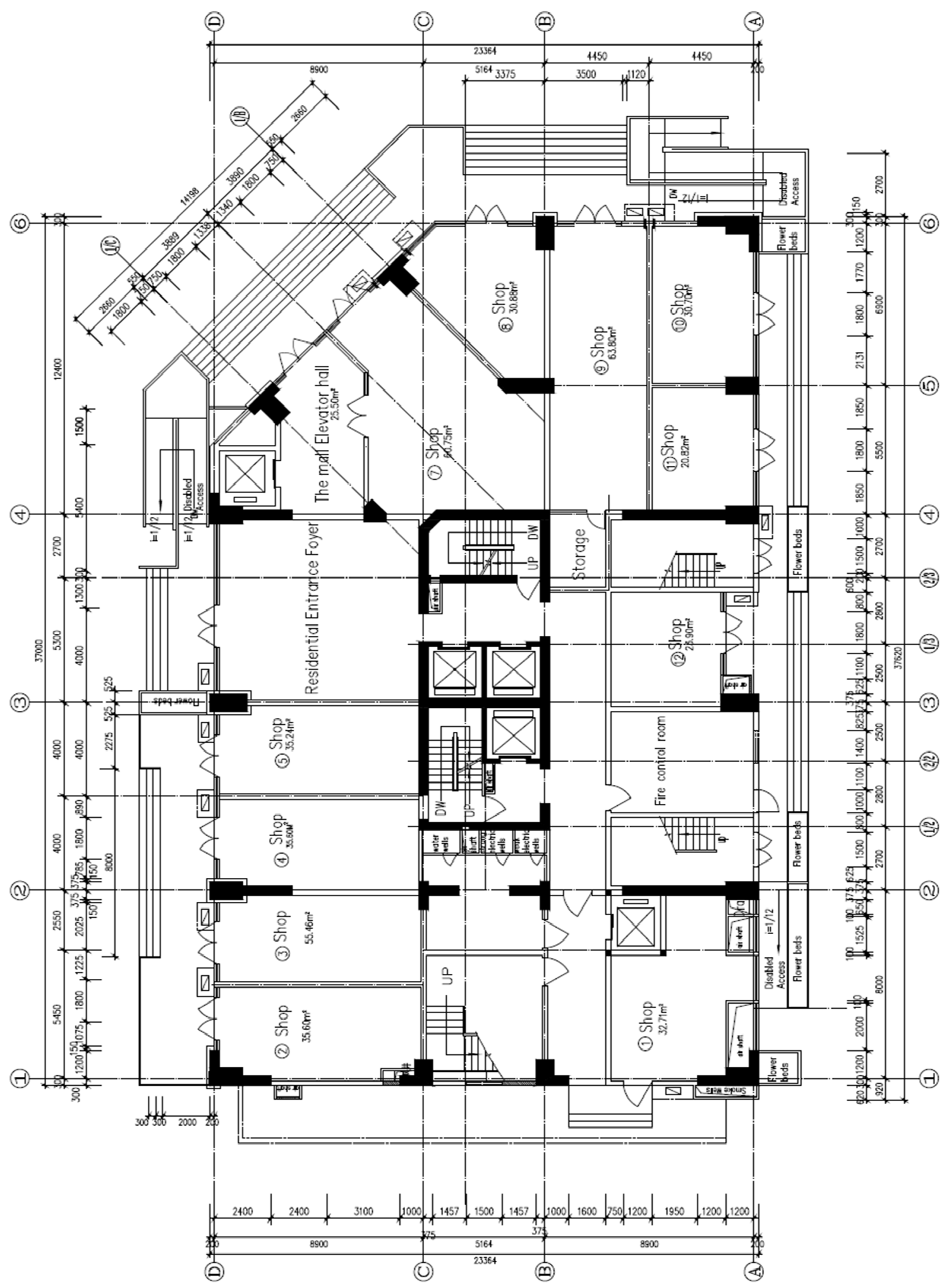

Figure 8. Plan view of first floor of the building. 


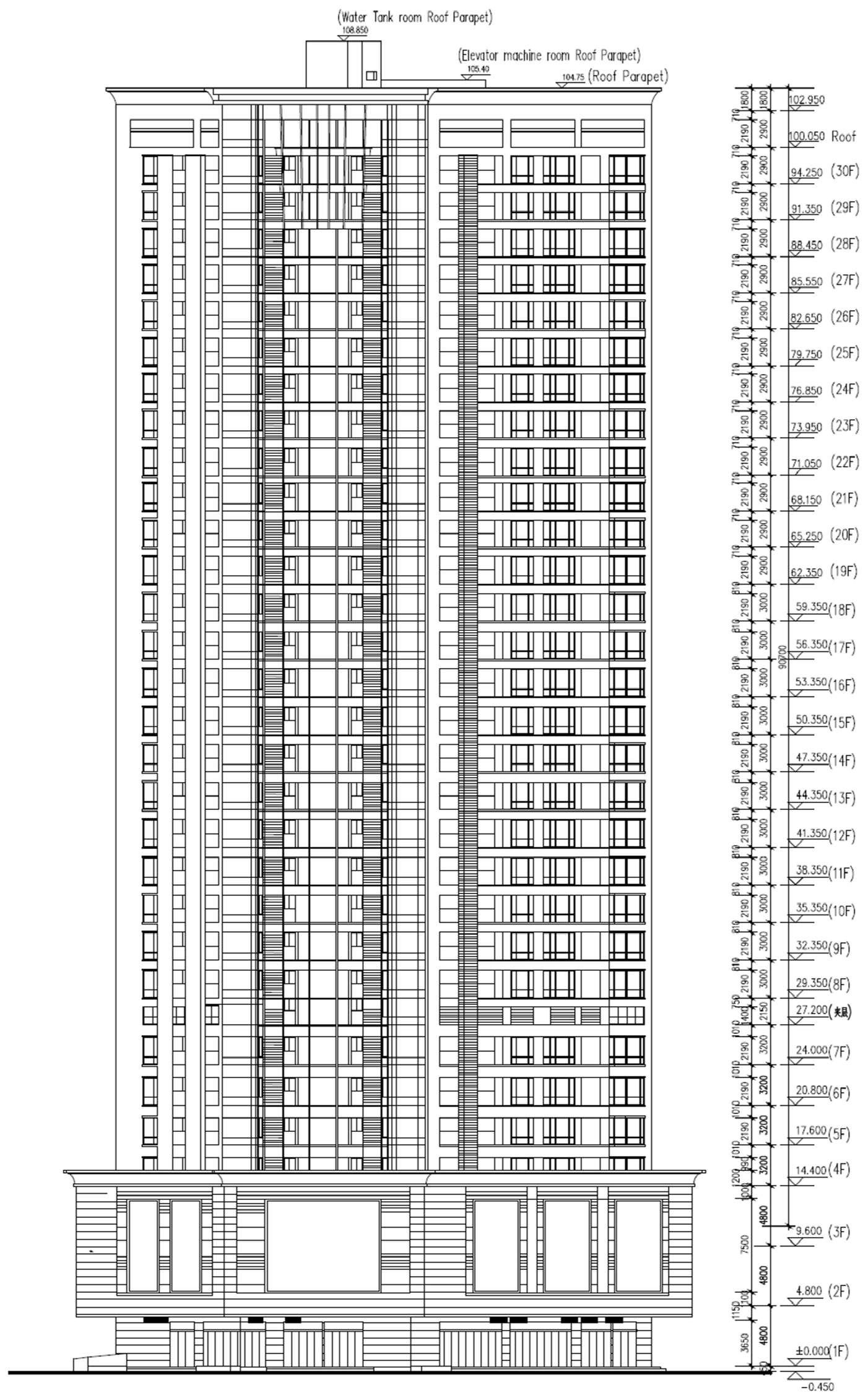

Figure 9. Elevation view of the building. 
Environmental conditions: The environmental data were taken from the Korean meteorological administration [37]. The site of the building is in the southeast of Korea. The average $\mathrm{CO}_{2}$ concentration of the indoor environment is $0.08 \%$ and of the outdoor environment is $0.04 \%$. The average relative humidity of the indoor environment is $55 \%$ and of the outdoor environment is $65 \%$. The average temperature of the indoor environment is $18.5^{\circ} \mathrm{C}$. For the local region of the building, the average outdoor temperature in spring (from March to May), in summer (from June to August), in autumn (from September to November), and in winter (from December to February) is $15.7{ }^{\circ} \mathrm{C}, 26.0^{\circ} \mathrm{C}, 19.6^{\circ} \mathrm{C}$, and $7.1^{\circ} \mathrm{C}$, respectively. The average outdoor temperature over one year is approximately $17.1^{\circ} \mathrm{C}$.

Material properties: The mixing proportions of concrete are shown in Table 6. The slag replacement level is $40 \%$. From the 1st floor to 10th floor, the compressive strength of concrete is $64.8 \mathrm{MPa}$, and from the 11th floor to 30th floor, the compressive strength of concrete is $52.3 \mathrm{MPa}$. The transport distances for OPC, GGBFS, fine aggregate, coarse aggregate, and superplasticizer are $25 \mathrm{~km}, 25 \mathrm{~km}, 20 \mathrm{~km}, 20 \mathrm{~km}$, and $10 \mathrm{~km}$, respectively. Using building drawings, we can calculate the volume of concrete for different floors and different structural members, such as columns, slabs, beams, stairs, and shear walls. As shown in Table 7, the total volume of concrete is $10,769 \mathrm{~m}^{3}$. Similarly, using building drawings, we can calculate the surface area of concrete for different floors and different structural members. As shown in Table 8, the total surface area of concrete is $79,228 \mathrm{~m}^{2}$. The slab and shear wall have a flat shape and larger surface area than that of other structural elements. Four-millimeter polymer waterproof coating is used as the finishing material $\left(\beta_{f m}=0.48\right)$ [33-36]. The average crack depth of a structural member is $0.18 \mathrm{~mm}\left(\beta_{c r}=1.5\right)$ [33-36].

Table 6. Mixing proportions of concrete in building.

\begin{tabular}{cccccccc}
\hline Floor & $\begin{array}{c}\text { Strength } \\
(\mathbf{M P a})\end{array}$ & $\begin{array}{c}\text { Water } \\
\left(\mathbf{k g} / \mathbf{m}^{\mathbf{3}} \mathbf{)}\right.\end{array}$ & $\begin{array}{c}\text { OPC } \\
\left(\mathbf{k g} / \mathbf{m}^{\mathbf{3}}\right)\end{array}$ & $\begin{array}{c}\text { GGBFS } \\
\left(\mathbf{k g} / \mathbf{m}^{\mathbf{3}}\right)\end{array}$ & $\begin{array}{c}\text { Fine Aggregate } \\
\left(\mathbf{k g} / \mathbf{m}^{\mathbf{3}}\right)\end{array}$ & $\begin{array}{c}\text { Coarse Aggregate } \\
\left(\mathbf{k g} / \mathbf{m}^{\mathbf{3}}\right)\end{array}$ & Superplasticizer \\
\hline $1 \mathrm{~F} \sim 10 \mathrm{~F}$ & 64.8 & 165 & 248 & 165 & 780 & 874 & $3.5 \%$ \\
$11 \mathrm{~F} \sim 30 \mathrm{~F}$ & 52.3 & 174 & 209 & 140 & 811 & 941 & $1.0 \%$ \\
\hline
\end{tabular}

Table 7. Volume of concrete for different floors.

\begin{tabular}{ccccccc}
\hline \multicolumn{7}{c}{ Concrete Volume $\left(\mathbf{m}^{\mathbf{3}}\right)$} \\
\hline Floor & Column & Slab & Shear Wall & Beam & Stairs & Total \\
\hline 1F-3F & 77.32 & 160.65 & 150.88 & 34.12 & 6.38 & \\
$4 \mathrm{~F}-30 \mathrm{~F}$ & 51.55 & 160.65 & 100.59 & 34.12 & 4.25 & \\
Total & 1623.72 & 4819.5 & 3168.48 & 1023.6 & 133.98 & $10,769.28$ \\
\hline
\end{tabular}

Table 8. Surface area of concrete for different floors.

\begin{tabular}{ccccccc}
\hline \multicolumn{7}{c}{ Area of Each Structure $\left(\mathbf{m}^{\mathbf{2}}\right)$} \\
\hline Floor & Column & Slab & Shear Wall & Beam & Stairs & Total \\
\hline 1F-3F & 364.50 & 1475.90 & 893.03 & 243.08 & 59.55 & \\
$4 \mathrm{~F}-30 \mathrm{~F}$ & 243.03 & 1475.90 & 595.35 & 243.08 & 39.70 & \\
Total & 7654.5 & 44,277 & $18,753.63$ & 7292.4 & 1250.55 & $79,228.08$ \\
\hline
\end{tabular}

Figure 10 shows the carbonation depth of different floors. The compressive strength of concrete in floors 1-10 (64.8 MPa) is higher than that in floors 11-30 (52.3 MPa). After 50 years of exposure, the calculated carbonation depth for floors $1-10$ is approximately $14 \mathrm{~mm}$, while the calculated carbonation depth for floors 11-30 is approximately $22 \mathrm{~mm}$. When the compressive strength of the concrete increases, the carbonation depth decreases. 


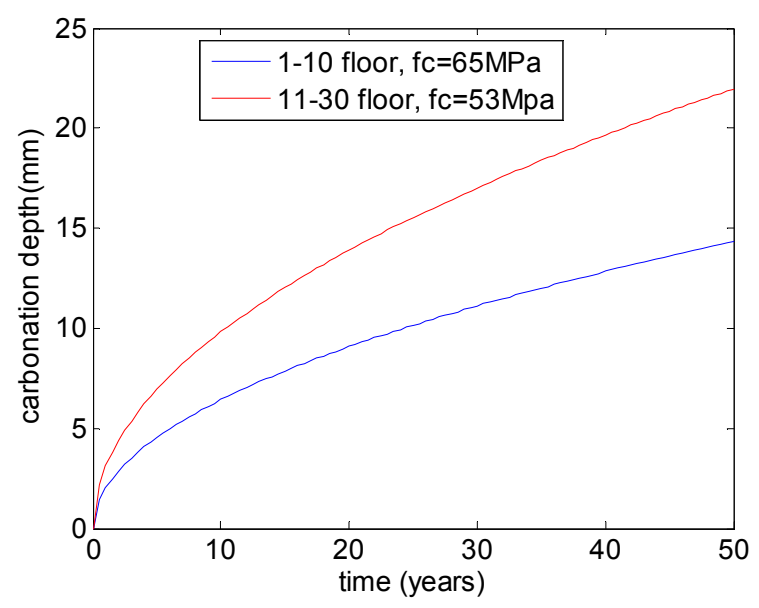

Figure 10. Carbonation depth of different floors.

Figure 11 shows the $\mathrm{CO}_{2}$ uptake of different floors. After 50 years of exposure, by using Equation (9), the sum of $\mathrm{CO}_{2}$ uptake for floors 1-10 is approximately $3.17 \times 10^{4} \mathrm{~kg}$, while the sum of $\mathrm{CO}_{2}$ uptake for floors 11-30 is approximately $8.13 \times 10^{4} \mathrm{~kg}$. Hence, the $\mathrm{CO}_{2}$ uptake for the total building is determined to be approximately $11.3 \times 10^{4} \mathrm{~kg}$.

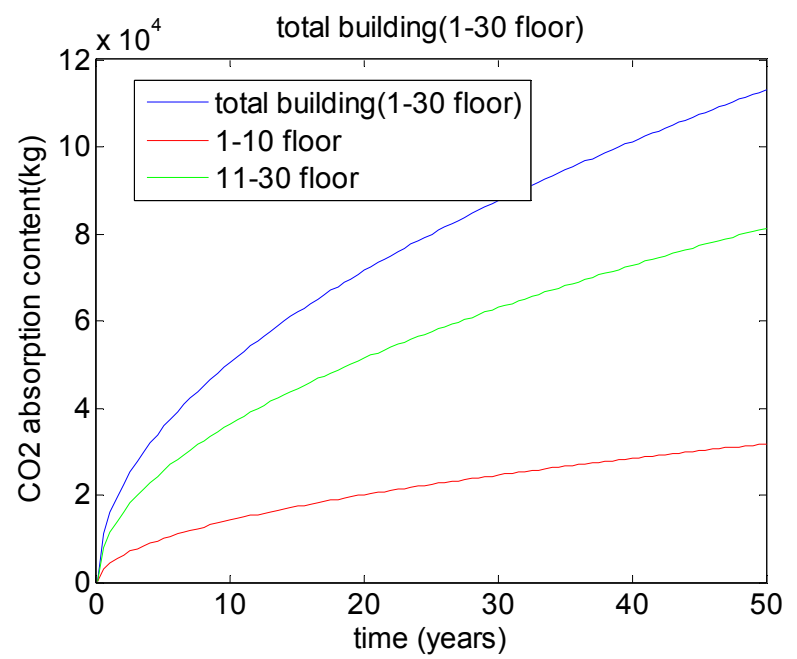

Figure 11. $\mathrm{CO}_{2}$ uptake of different floors.

Figure 12 shows the $\mathrm{CO}_{2}$ uptake ratio of all buildings. Using Equation (1), we can calculate the sum of $\mathrm{CO}_{2}$ emission for floors 1-10 (approximately $9.43 \times 10^{5} \mathrm{~kg}$ ) and for floors 11-30 (approximately $15.07 \times 10^{5} \mathrm{~kg}$ ). The $\mathrm{CO}_{2}$ emission for the total building is approximately $24.5 \times 10^{5} \mathrm{~kg}$. Furthermore, using Equation (10), we can calculate the $\mathrm{CO}_{2}$ uptake ratio of all buildings. After 50 years, the ratio between the absorbed $\mathrm{CO}_{2}$ and the emitted $\mathrm{CO}_{2}$ is approximately $4.61 \%$ $\left(11.3 \times 10^{4} / 24.5 \times 10^{5}=4.61 \%\right)$. As shown in Table 1 , using slag in the concrete industry can reduce $\mathrm{CO}_{2}$ emissions. As shown in Figure 7, using slag will increase the carbonation depth of concrete and absorb more $\mathrm{CO}_{2}$ from the surrounding environment. On the other hand, note that after the carbonation depth of concrete exceeds the protective layer of steel rebar, corrosion of steel rebar will be initiated. More attention with respect to carbonation-induced corrosion should be paid to slag-blended concrete. 


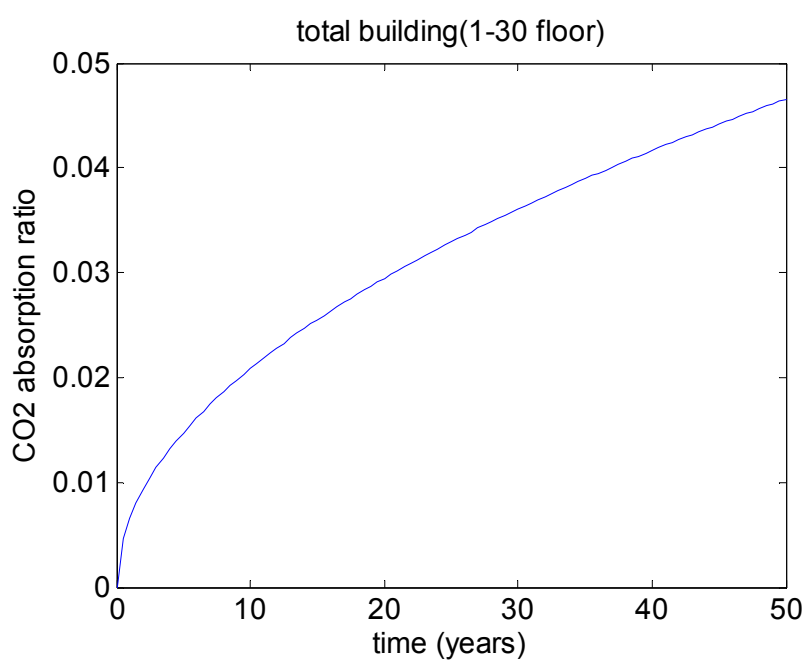

Figure 12. $\mathrm{CO}_{2}$ uptake ratio of building.

\subsection{Discussion about Life Cycle Assessment, Service Life, Carbonation, and $\mathrm{CO}_{2}$ Uptake after Demolitions}

The life cycle of the construction system consists of four stages: production stage, construction stage, use stage, and demolition stage. The production stage involves obtaining raw materials and processing them, transport to the concrete plant, concrete mixing, steel bar production, and transport to the building site. The construction stage is the structure building process. The use stage is the longest-lasting stage. Finally, in the demolition stage, the structure is pulled down and the demolished concrete is crushed and recycled. During the use stage, carbon dioxide will be absorbed due to carbonation. During the demolition stage, after concrete is demolished and crushed, the surface area of concrete will significantly increase, fresh uncarbonated concrete will be exposed to the environmental air, a new cycle of carbonation will begin, and more carbon dioxide will be absorbed [22].

On the other hand, durability, such as carbonation, must be considered in the use stage. The service life of RC structures consists of two distinct phases. The first phase is the initiation of corrosion; $\mathrm{CO}_{2}$ penetrates the concrete cover and leads to the loss of reinforcement passivity. The second phase is the propagation of corrosion. Once a limiting state is reached, beyond which the consequences of corrosion cannot be tolerated, the service life ends. We can extend the technical lifetime of an RC structure via maintenance or repair, but this will involve high costs. It is important to consider service life in the life cycle assessment of buildings [22]. As shown in Figure 10, after 50 years of exposure, the carbonation depth of concrete $(22 \mathrm{~mm})$ is less than the concrete cover depth $(30 \mathrm{~mm})$. This building is in the corrosion initiation phase.

In this article, the crushed concrete is assumed to be used as back filler after demolition. The average diameter of crushed concrete in Korea is $25 \mathrm{~mm}$ [24], the average $\mathrm{CO}_{2}$ concentration below the ground is $0.05 \%$ [24], and the average relative humidity below the ground is $75 \%$ [24]. Using carbonation rate relations, the crushed concrete takes 59.51 years to fully carbonate. Considering carbonation both during the use stage (50 years) and after the demolition stage (59.51 years), the total carbon dioxide uptake ratio is $19.21 \%$. On the other hand, if we only consider carbonation during the use stage (50 years), the carbon dioxide uptake ratio is $4.61 \%$. Hence, a major $\mathrm{CO}_{2}$ uptake will take place when the concrete structures are demolished.

\section{Conclusions}

(1) This paper presents a numerical procedure for quantitatively evaluating the amount of carbon dioxide emissions and absorption for slag-blended concrete structures. The analysis presents theoretical innovations: first, using a slag-blended cement hydration model, we calculate the reaction degrees of cement and slag and evaluate concrete material properties, such as carbonatable materials content and 
porosity; second, using a micro-structure-based carbonation model, we calculate the carbonation depth of slag-blended concrete; third, using building drawings and carbonation depth, we calculate the carbon dioxide uptake of concrete. The proposed numerical procedure can be applied for evaluating the $\mathrm{CO}_{2}$ uptake of buildings with different building types, different concrete mixing proportions, and different environment conditions.

(2) Using slag in the concrete industry can reduce $\mathrm{CO}_{2}$ emissions, increase the carbonation depth of concrete, and uptake more $\mathrm{CO}_{2}$ from the surrounding environment. A real building case study that considered $\mathrm{CO}_{2}$ uptake performance was carried out. The calculation results show that for concrete containing $40 \%$ slag as binders, $4.61 \%$ (113 tons) carbon dioxide will be absorbed during 50 years of service life. $\mathrm{CO}_{2}$ uptake ability closely relates to the surface area of structural elements. Slabs and shear walls have a flat shape and larger surface area than other structural elements and make significant contributions to $\mathrm{CO}_{2}$ uptake. On the other hand, a major $\mathrm{CO}_{2}$ uptake will take place when the concrete structures are demolished and crushed because of the increase in the exposed surface area of uncarbonated concrete to the air.

(3) In the life cycle assessment of concrete buildings, different phases of service life, such as the initiation of corrosion and the propagation of corrosion, should be taken into account. Because slag-blended concrete shows higher carbonation depth than control concrete, more attention with respect to carbonation-induced corrosion should be paid to slag-blended concrete.

(4) The proposed numerical procedure is not perfect and has some limitations: first, the diffusion-reaction process in finishing materials and substrate concrete needs further study. Second, concrete durability includes many aspects, such as freezing and thawing, chloride penetration, carbonation, sulfate attack, and corrosion. The interactions between carbonation and other durability aspects require further study. Third, reinforced concrete structures have many structural styles, such as buildings, bridges, and dams. This paper focuses on the carbon dioxide uptake of RC buildings. For other structural styles, the carbon dioxide uptake amount may differ from that presented in this study.

Acknowledgments: This research was supported by the Basic Science Research Program through the National Research Foundation of Korea (NRF), funded by the Ministry of Science, ICT and Future Planning (No. 2015R1A5A1037548).

Author Contributions: Han-Seung Lee performed the accelerated carbonation experiment; Xiao-Yong Wang analyzed the experimental results; Han-Seung Lee and Xiao-Yong Wang wrote the paper.

Conflicts of Interest: The authors declare no conflict of interest.

\section{References}

1. Jung, Y.B.; Yang, K.H. Mixture-Proportioning Model for Low- $\mathrm{CO}_{2}$ Concrete Considering the Type and Addition Level of Supplementary Cementitious Materials. J. Korea Concr. Inst. 2015, 27, 427-434. [CrossRef]

2. Pacheco-Torgal, F.; Miraldo, S.; Labrincha, J.A.L.; de Brito, J. An overview on concrete carbonation in the context of eco-efficient construction. Constr. Build. Mater. 2012, 36, 141-150. [CrossRef]

3. Sulapha, P.; Wong, S.F.; Wee, T.H.; Swaddiwudhipong, S. Carbonation of concrete containing mineral admixtures. ASCE J. Mater. Civ. Eng. 2003, 15, 134-143. [CrossRef]

4. Elke, G.; van den Philip, H.; de Nele, B. Carbonation of slag concrete: Effect of the cement replacement level and curing on the carbonation coefficient-Effect of carbonation on the pore structure. Cem. Concr. Compos. 2013, 35, 39-48.

5. Sisomphon, K.; Franke, L. Carbonation rates of concretes containing high volume of pozzolanic materials. Cem. Concr. Res. 2007, 37, 1647-1653. [CrossRef]

6. Monkman, S.; Shao, Y. Carbonation Curing of Slag-Cement Concrete for Binding $\mathrm{CO}_{2}$ and Improving Performance. J. Mater. Civ. Eng. 2010, 22, 296-304. [CrossRef]

7. Bernal, S.A.; Provis, J.L.; Gutierrez, R.M.; Deventer, J.S.J. Accelerated carbonation testing of alkali-activated slag/metakaolin blended concretes: Effect of exposure conditions. Mater. Struct. 2015, 48, 653-669. [CrossRef] 
8. Papadakis, V.G.; Tsimas, S. Effect of supplementary cementing materials on concrete resistance against carbonation and chloride ingress. Cem. Concr. Res. 2000, 30, 291-299. [CrossRef]

9. Demis, S.; Papadakis, V.G. A software-assisted comparative assessment of the effect of cement type on concrete carbonation and chloride ingress. Comput. Concr. 2012, 10, 391-407. [CrossRef]

10. Hasanbeigi, A.; Price, L.; Lin, E. Emerging energy-efficiency and $\mathrm{CO}_{2}$ emission-reduction technologies for cement and concrete production: A technical review. Renew. Sustain. Energy Rev. 2012, 16, 6220-6238. [CrossRef]

11. Gartner, E.M. Industrially interesting approaches to “low- $\mathrm{CO}_{2}$ ” cements. Cem. Concr. Res. 2004, 34, 1489-1498. [CrossRef]

12. Miller, S.A.; Horvath, A.; Monteiro, P.J.M.; Ostertag, C.P. Greenhouse gas emissions from concrete can be reduced by using mix proportions, geometric aspects, and age as design factors. Environ. Res. Lett. 2015, 10, 114017. [CrossRef]

13. Roh, S.; Tae, S.; Shin, S. Development of building materials embodied greenhouse gases assessment criteria and system (BEGAS) in the newly revised Korea Green Building Certification System (G-SEED). Renew. Sustain. Energy Rev. 2014, 35, 410-421. [CrossRef]

14. Kim, R.; Tae, S.; Yang, K.; Kim, T.; Roh, S. Analysis of lifecycle $\mathrm{CO}_{2}$ reduction performance for long-life apartment house. Environ. Prog. Sustain. Energy 2015, 34, 555-566. [CrossRef]

15. Tae, S.; Baek, C.; Shin, S. Life cycle $\mathrm{CO}_{2}$ evaluation on reinforced concrete structures with high-strength concrete. Environ. Impact Assess. Rev. 2011, 31, 253-260. [CrossRef]

16. Tae, S.; Shin, S.; Woo, J.; Roh, S. The development of apartment house life cycle $\mathrm{CO}_{2}$ simple assessment system using standard apartment houses of South Korea. Renew. Sustain. Energy Rev. 2011, 15, 1454-1467. [CrossRef]

17. Kim, T.; Tae, S.; Roh, S. Assessment of the $\mathrm{CO}_{2}$ emission and cost reduction performance of a low-carbon-emission concrete mix design using an optimal mix design system. Renew. Sustain. Energy Rev. 2013, 25, 729-741. [CrossRef]

18. Roh, S.; Tae, S.; Shin, S.; Woo, J. Development of an optimum design program (SUSB-OPTIMUM) for the life cycle $\mathrm{CO}_{2}$ assessment of an apartment house in Korea. Build.Environ. 2014, 73, 40-54. [CrossRef]

19. Ji, C.; Hong, T.; Park, H.S. Comparative analysis of decision-making methods for integrating cost and $\mathrm{CO}_{2}$ emission-Focus on building structural design. Energy Build. 2014, 72, 186-194. [CrossRef]

20. Yepes, V.; Marti, J.V.; Garcia-Segura, T. Cost and $\mathrm{CO}_{2}$ emission optimization of precast-prestressed concrete U-beam road bridges by a hybrid glowworm swarm algorithm. Autom. Constr. 2015, 49, 123-134. [CrossRef]

21. Lee, S.; Park, W.; Lee, $\mathrm{H}$. Life cycle $\mathrm{CO}_{2}$ assessment method for concrete using $\mathrm{CO}_{2}$ balance and suggestion to decrease $\mathrm{LCCO}_{2}$ of concrete in South-Korean apartment. Energy Build. 2013, 58, 93-102. [CrossRef]

22. Garcia Segura, T.; Yepes, V.; Alcala, J. Life cycle greenhouse gas emissions of blended cement concrete including carbonation and durability. Int. J. Life Cycle Assess. 2014, 19, 3-12. [CrossRef]

23. Lagerblad, B. Carbon Dioxide Uptake during Concrete Life Cycle-State of the Art; Background Report; Nordic Innovation Center: Palo Alto, CA, USA, 2006.

24. Yang, K.; Tae, S. Carbonation and $\mathrm{CO}_{2}$ uptake of concrete. Environ. Impact Assess. Rev. 2014, 46, 43-52. [CrossRef]

25. Kashef-Haghighi, S.; Shao, Y.; Ghoshal, S. Mathematical modeling of $\mathrm{CO}_{2}$ uptake by concrete during accelerated carbonation curing. Cem. Concr. Res. 2015, 67, 1-10. [CrossRef]

26. Wang, X.Y.; Lee, H.S. Modeling the hydration of concrete incorporating fly ash or slag. Cem. Concr. Res. 2010, 40, 984-996. [CrossRef]

27. Lee, H.S.; Wang, X.Y.; Zhang, K.N.; Koh, K.T. Analysis of the Optimum Usage of Slag for the Compressive Strength of Concrete. Materials 2015, 8, 1213-1229. [CrossRef]

28. Maekawa, K.; Ishida, T.; Kishi, T. Multi-Scale Modeling of Structural Concrete; Taylor \& Francis: London, UK; New York, NY, USA, 2009.

29. Ishida, T.; Luan, Y.; Sagawa, T.; Nawa, T. Modeling of early age behavior of blast furnace concrete based on micro-physical properties. Cem. Concr. Res. 2011, 41, 1357-1367. [CrossRef]

30. Van Breugel, K. Numerical simulation of hydration and microstructural Development in hardening cement-based materials (I) theory. Cem. Concr. Res. 1995, 25, 319-331. [CrossRef]

31. Van Breugel, K. Numerical simulation of hydration and microstructural development in hardening cement-based materials: (II) applications. Cem. Concr. Res. 1995, 25, 522-530. [CrossRef] 
32. Kwon, S.J.; Na, U.J. Prediction of Durability for RC Columns with Crack and Joint under Carbonation Based on Probabilistic Approach. Int. J. Concr. Struct. Mater. 2011, 5, 11-18. [CrossRef]

33. Lee, H.S.; Wang, X.Y. Prediction of the Carbonation Depth of Concrete with a Mortar Finish. Key Eng. Mater. 2008, 385-387, 633-636. [CrossRef]

34. Lee, S.H.; Lee, H.S.; Park, K.B. Study on an FEM Analysis to Evaluate Restrain-Performance of Surface-Finishes for Carbonation. Key Eng. Mater. 2007, 348-349, 477-480. [CrossRef]

35. Yoda, A. Carbonation of Portland blast furnace slag cement concrete by 40 year natural aging and preventive effect of finishing materials. Cem. Sci. Concr. Technol. 2002, 56, 449-454.

36. Lee, W.J. A Study about the Deterioration Behavior of Surface Finishing Materials and the Depression Effect for Carbonation in the Reinforced Concrete Building. Ph.D. Thesis, The University of Tokyo, Tokyo, Japan, 2009.

37. Korea Meteorological Administration. Available online: http://www.kma.go.kr/ (accessed on 28 March 2016).

(C) 2016 by the authors; licensee MDPI, Basel, Switzerland. This article is an open access article distributed under the terms and conditions of the Creative Commons by Attribution (CC-BY) license (http://creativecommons.org/licenses/by/4.0/). 